\title{
PENGARUH PROMOSI DI MEDIA SOSIAL DAN WORD OF MOUTH TERHADAP KEPUTUSAN PEMBELIAN (STUDI KASUS PADA KEDAI BONTACOS, JOMBANG)
}

\author{
Bagas Aji Pamungkas \\ Siti Zuhroh \\ zuhroh.stie@gmail.com \\ STIE PGRI Dewantara Jombang
}

\begin{abstract}
Penelitian ini bertujuan mengetahui dan menjelaskan pengaruh promosi melalui media sosial dan word of mouth terhadap keputusan pembelian konsumen di kedai Bontacos baik secara parsial ataupun simultan. Penelitian ini menggunakan pendekatan kuantitatif. Sampel penelitian ini adalah 100 konsumen kedai Bontacos dengan menggunakan metode non probability sampling serta teknik accidental sampling. Instrumen penelitian ini menggunakan kuesioner dan dianalisis menggunakan analisis regresi berganda.
\end{abstract}

Hasil penelitian ini menunjukkan bahwa promosi menggunakan media sosialdan word of mouthsecatra parsial dan simultan memiliki pengaruh terhadap keputusan pembelian.Penelitian ini memberikan konstribusi bagi Pemasar kedai Bontacos terkait strategi promosi di media sosial dan word of mouth yang efektif.

Kata kunci : Promosi, media sosial, word of mouth, keputusan pembelian

\section{PENDAHULUAN}

\section{Latar Belakang}

Perkembangan dunia bisnis khususnya dibidang kuliner memicu munculnya pengusaha-pengusaha baru. Bisnis kuliner termasuk bisnis yang cukup menjanjikan karena berhubungan dengan kebutuhan dasar manusia, yaitu makan. Munculnya berbagai makanan yang unik, adanya wisata kuliner, dan tren kuliner sebagai gaya hidup masyarakat, menjadi bukti bahwa bisnis ini berkembang dengan pesat. Pertumbuhan bisnis kuliner tersebut juga terjadi di Jombang yang saat ini banyak bermunculan rumah makan, kedai, atau warung makan baru, salah satunya adalah Bontacos.

Bontacos merupakan sebuah kedai makanan di Jombang yang pertama dan satu- satunya yang menawarkan menu makanan khas Meksiko Dalam upaya pemasaran, Bontacos mengalami berbagai hambatan. Kondisi tersebut dapat dilihat dari omzet Bontacos yang tidak stabil dan cenderung menurun dalam enam bulan pertama.

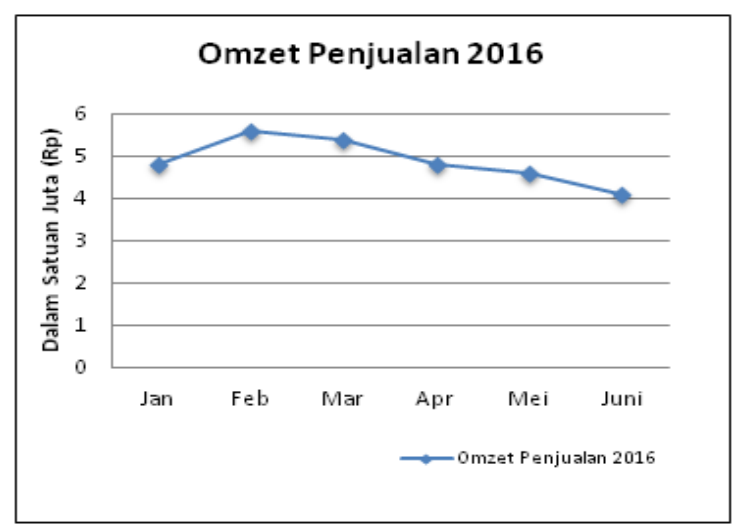

Gambar 1: Grafik Omzet Bontacos Sumber : laporan keuangan Bontacos 
Persaingan dalam bisnis kuliner menjadi salah satu penyebab terjadinya hal tersebut. Banyaknya cafe, angkringan atau penjual makanan online di jombang membuat persaingan semakin ketat.

Kendala yang dihadapi Kedai Bontacos lainnya adalah kurangnya informasi yang didapatkan konsumen tentang Bontacos. Informasi tentang produk merupakan salah satu faktor penting yang mempengaruhi konsumen dalam pengambilan keputusan pembelian. Informasi yang didapat oleh konsumen baik positif maupun negatif akan mempengaruhi persepsi konsumen terhadap suatu produk. Beberapa pengetahuan mungkin diperoleh dengan menginterpretasikan informasi yang ditemukan di lingkungan selama proses pembuatan keputusan (J. Supranto dan Nandan L., 2011).

Kotler (2004) menyatakan bahwa keputusan pembelian adalah suatu proses penyelesaian masalah yang terdiri dari menganalisa atau pengenalan kebutuhan dan keinginan, pencarian informasi, penelitian sumber-sumber informasi terhadap alternatif pembelian, keputusan pembelian, dan perilaku setelah pembelian. Dari pernyataan tersebut dapat dikatakan bahwa pencarian informasi dan evaluasi merupakan hal yang dilakukan konsumen sebelum melakukan keputusan pembelian.

Menurut Sutisna (2001), "setidaktidaknya ada dua kriteria evaluasi alternatif. Pertama, adalah manfaat yang diperoleh dengan membeli produk. Kedua, kepuasan yang diharapkan".

Philip Kotler (1998) mengemukakan, "konsumen mempelajari merek-merek yang tersedia dari ciri-cirinya. Informasi ini digunakan untuk mengevaluasi semua alternatif yang ada dalam menentukan keputusan pembeliannya. Dari beberapa pernyataan diatas dapat disimpulkan bahwa konsumen akan melakukan evaluasi terhadap berbagai alternatif pilihan yang ada dan memilih produk mana yang dapat memberikan manfaat serta kepuasan. Konsumen juga akan mempelajari dan mengumpulkan informasi tentang produk yang akan dibeli.

Penyebaran informasi dapat dilakukan dengan promosi. Dalam hal ini Bontacos menggunakan media sosial seperti Facebook (Gambar 2) dan Instagram sebagai sarana promosi dan berkomunikasi dengan konsumen.

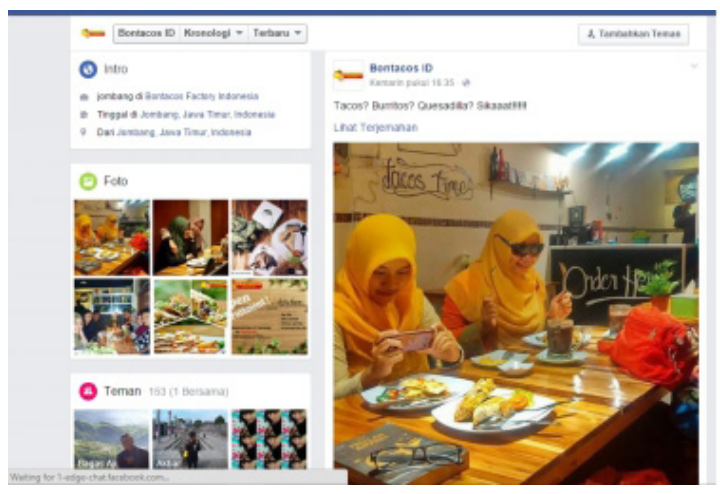

Gambar 2:Facebook dan Instagram Bontacos Sumber : Facebook dan Instagram

Masyarakat di era global mulai memanfaatkan internet sebagai sarana untuk mencari berbagai informasi. Perkembangan teknologi internet juga telah mengubah cara manusia dalam berkomunikasi. seseorang dapat berkomunikasi dengan orang lain kapanpun dan dimanapun orang itu berada serta dapat berbagi segala macam informasi tanpa ter-hambat ruang dan waktu. Sebab melalui internet, segala bentuk halangan geogafis terhapuskan, batas negarapun ditiadakan. Manusia modern dimana pun di dunia ini berada dapat tersambung melalui internet (Hermawan, 2012).

Selain merubah perilaku manusia, dalam berkomunikasi, intenet juga memberikan perubahan berarti dalam upaya pemasaran (Hermawan, 2012). pemasaran internet (e-marketing) adalah pemasaran yang meng- 
gunakan teknologi internet sebagai saluran penyampaian isi pesan kepada banyak orang secara bersamaan dan seketika dalam suatu kurun waktu tertentu (Wikipedia, 2016).

Pada awal tahun 2016 pengguna internet di Indonesia mencapai 88,1 juta pengguna. Saat ini ada sekitar 79 juta pengguna aktif media sosial di Indonesia (wearesocial.com, 2016).

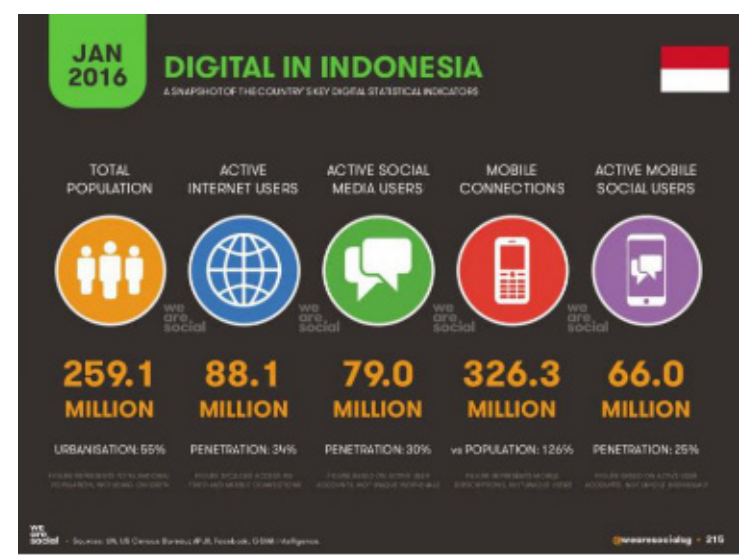

Gambar 3: Jumlah pengguna internet di Indonesia Sumber : wearesocial.com

Peningkatan jumlah pengguna internet dan media sosial menjadi peluang yang sangat besarbagi para pelaku bisnisuntuk memasarkan produk-produknya. Hayden dan Herman dalam Hermawan (2012) menggunakan istilah redhot, untuk menggambarkan peluang pemasar yang sedemikian besar dalam pemasaran via internet. Dengan internet pemasaran produk dapat lebih terbantu, karena internet memungkinkan proses pemasaran yang lebih efektif, respon yang lebih cepat dan biaya yang lebih murah (Hermawan, 2012). Dengan biaya yang murah dan penyebaran informasi yang cepat diharapkan dapat meningkatkan penjualan sehingga Bontacos dapat mencapai omzet yang sesuai target.

Melalui media sosial Bontacos juga dapat berkomunikasi dengan konsumen secara interaktif. Pemasar juga dapat mengetahui respon konsumen terhadap produk yang ditawarkan dengan melihat testimoni atau komentar yang diposting. Komunikasi yang baik dapat mempererat hubungan baik dengan konsumen. Hal tersebut secara tidak langsung akan menjadi kepuasan tersendiri bagi konsumen karena konsumen merasa diperhatikan. Ketika konsumen mendapat kepuasan, maka konsumen akan memberikan testimoni yang positif kemudian akan merekomendasikan kepada orang lain.

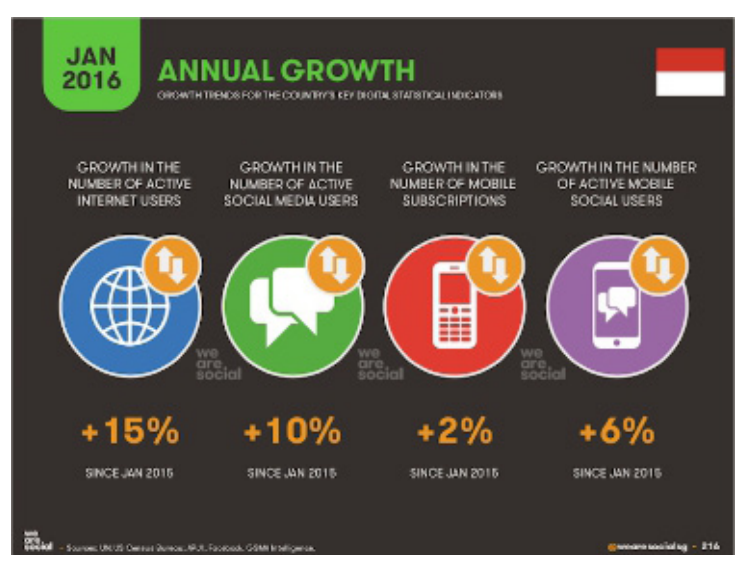

Gambar 4: Prosentase pertumbuhan pengguna internet di Indonesia

Sumber : wearesocial.com

Rekomendasi dapat dilakukan melalui media sosial atau dari mulut ke mulut. Komunikasi dari mulut ke mulut $($ WOM $=$ Word Of Mouth) adalah dimana para individu saling menukar informasi, khususnya tentang halhal yang bagus sehingga dapat mempengaruhi keputusan konsumen dan akan membuat bisnis mencapai sukses (J. Supranto dan Nanda L, 2011). Pernyataan tersebut senada dengan penelitian yang dilakukan Onbee Marketing Research bekerjasama dengan Majalah SWA (2009) membuktikan bahwa tingkat WOM Conversation (menceritakan kembali kepada orang lain) sebesar $85 \%$ dan menjadikan WOM sebagai sumber informasi untuk mengubah keputusannya sebesar $67 \%$. Efek dari adanya WOM ini sangat besar, bahkan banyak pemasar yang telah memanfaatkannya karena berasal dari sumber terpercaya dan 
memberikan pengaruh.

Tujuan penelitian ini adalah menguji dan menjelaskanpengaruh promosi di media sosial danword of mouth(WOM) terhadap keputusan pembelian konsumen Bontacos.

\section{TINJAUAN PUSTAKA}

\section{Keputusan Pembelian}

Keputusan pembelian adalah keputusan konsumen mengenai preferensi atasmerekmerek yang ada di dalam kumpulan pilihan (Kotler dan Keler, 2009).Keputusan pembelian yang dilakukan oleh para konsumen melalui lima tahap yang disajikan pada Gambar yaitu: pengenalan kebutuhan, pencarian informasi, evaluasi alternatif, keputusan pembelian, dan perilaku pasca pembelian.

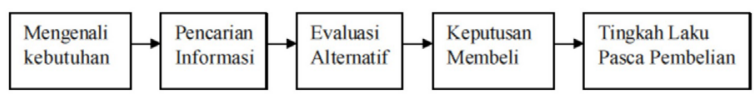

Gambar 5: Proses Keputusan Pembelian Sumber: Kotler dan Amstrong (2012)

\section{Promosi}

Promosi sebagai unsur utama dalam kampanye pemasaran merupakan kumpulan alat-alat yang insentif yang sebagian besar berjangka pendek, yang dirancang untuk merangsang pembelian produk atau jasa tertentu dengan lebih cepat dan lebih besar oleh konsumen atau pedagang (Kotler dan Keller, 2007). Selanjutnya Tjiptono (2008) menyatakan bahwa promosi merupakan salah satu faktor penentu keberhasilan suatu program pemasaran untuk memberikan informasi mengenai adanya suatu produk.

Dari definisi diatas dapat dikatakan bahwa promosi merupakan cara perusahaan memperkenalkan produknya dan mempengaruhi keputusan pembelian konsumen. Promosi yang disebut juga alat mengkomunikasikan produk telah mengalami perkembangan dimana pemasar lebih mudah dan lebih cepat dalam mempromosikan produknya. Hal ini disebabkan munculnya berbagai media baru yang dapat dimanfaatkan untuk menjangkau konsumen lebih cepat dan luas.

\section{Bentuk Komunikasi Pemasaran di Media Sosial}

Komunikasi pemasaran di era media sosial tidak terlepas dari komunikasi pemasaran di media sosial. Dua bentuk komunikasi pemasaran di media sosial yang umum digunakan yaitu:

1. Periklananmelaluimediasosial.Periklanan melalui media sosial adalah segala bentuk komunikasi nonpersonal berbayar, tentang sebuah organisasi, produk, jasa, atau ide yang menggunakan media sosial sebagai medianya (Belch, 2009). Kata "berbayar" menunjukkan bahwa sebuah pesan periklanan biasanya menggunakan media yang harus dibayar sedangkan kata "nonpersonal" menunjukkan bahwa pesan dalam periklanan disampaikkan kepada kelompok orang atau individual secara bersamaan dengan menggunakan media massa. (Wenats, dkk, 2012).

2. Pemasaran melalui media sosial. Selain iklan online, para pemasar juga menggunakan social community yang terdiri dari berbagai bentuk interaksi mulai dari forum (Kaskus atau Fashionesdaily), situs jejaring sosial (Facebook atau Instagram), dunia virtual (Second Life, There, atau Kaneva), games, situs berbagi (Flickr atau YouTube), hingga mikroblogging (Twitter). Menurut Tuten dalam Wenats (2012) pemasaran melalui media sosial adalah salah satu bentuk periklanan yang menggunakan media social community dimana pengiklan (pro- 
dusen atau pemilik merek) dapat langsung berinteraksi dan membangun dialog dengan para konsumennya. Menurut Taprial \& Kanwar (2012) sosial media memiliki beberapa keunggulan yang menjadikannya lebih kuat dibandingkan media tradisional: (1) Accessibility Sosial media mudah untuk diakses karena memerlukan sedikit atau tidak ada biaya sama sekali dalam penggunaanya. (2) Speed, konten yang dibuat dalam sosial media tersedia bagi semua orang yang berada dalam jaringan, forum, atau komunitas begitu diterbitkan. (3). Interactivity, media sosial dapat menampung dua atau lebih saluran komunikasi. (4). Longevity / Volativity, konten pada sosial media tetap dapat diakses pada waktu yang lama, atau bahkan selamanya. (5) Reach, Internet menawarkan jangkauan yang tidak terbatas ke semua konten yang tersedia.

Berdasarkan penjelasan diatas, dapat disimpulkan bahwa sosial media adalah suatu alat digital marketing yang dapat menjangkau semua kalangan, dengan biaya yang relatif terjangkau atau tidak menggunakan biaya sama sekali dan digunakan untuk menciptakan suatu komunitas, membangun hubungan, dan bertukar informasi dengan sesama pengguna sosial media dalam jangka waktu yang tidak terbatas.

\section{Hubungan Promosi Melalui Media Sosial dengan Keputusan Pembelian}

Tjiptono (2008) menyatakan bahwa promosi merupakan salah satu faktor penentu keberhasilan suatu program pemasaran untuk memberikan informasi mengenai adanya suatu produk. Media sosial saat ini menjadi salah satu alat yang banyak digunakan oleh pemasar dalam menyebarkan informasi tentang suatu produk kepada konsumen. Jaringan sosial media ini merupakan bentuk baru dari dialog antara "consumer-to-consumer" dan "businessto-consumer" yang memiliki implikasi besar terhadap pemasar. (Kotler \& Amstrong, 2012).

Hayden dan Herman dalam Hermawan (2012) menggunakan istilah red-hot, untuk menggambarkan peluang pemasar yang sedemikian besar dalam pemasaran via internet. Sosial media juga sarana komunitas online dimana orang dapat bersosialisasi dan bertukar informasi, yang bertujuan membangun hubungan dan membangun loyalitas pada konsumen. (A. Depito,2011). Social media marketing memungkinkan membangun hubungan sosial yang lebih personal dan dinamis dibandingkan dengan strategi marketing tradisional.

Promosi dengan menggunakan media sosial mempengaruhi keputusan pembelian. Hal tersebut sejalan dengan hasil penelitian yang dilakukan oleh Singgih Nurgiyantoro tahun 2014, menyebutkan bahwa promosi melalui media sosial berpengaruh positif dan signifikan terhadap keputusan pembelian konsumen dengan nilai koefisien regresi sebesar 0,792 dan keputusan pembelian dipengaruhi oleh strategi promosi melalui media sosial sebesar 34\%.

\section{Word Of Mouth (WOM)}

Kotler \& Keller (2007) mengemukakan bahwa word of mouth communication (WOM) atau komunikasi dari mulut ke mulut merupakan proses komunikasi yang berupa pemberian rekomendasi baik secara individu maupun kelompok terhadap suatu produk atau jasa yang bertujuan untuk memberikan informasi secara personal. Menurut Goyette, Ricard, Bergeron, dan Marticotte (2010) WOM didefinisikan sebagai pertukaran, aliran informasi, atau percakapan dua individu. 
Komunikasi dari mulut ke mulut merupakan salah satu saluran komunikasi yang sering digunakan oleh banyak perusahaan, karena komunikasi ini dinilai sangat efektif dalam memperlancar proses pemasaran dan mampu memberikan keuntungan kepada perusahaan.

Pemasaran dengan menggunakan word of mouth dapat juga disebut word of mouth marketing yaitu kegiatan pemasaran melalui perantara orang ke orang baik secara lisan, tulisan, maupun alat komunikasi elektronik yang berhubungan dengan pengalaman pembelian jasa atau pengalaman menggunakan produk atau jasa (Kotler \& Keller, 2009). Definisi lain dari word of mouth marketing menurut sumardy (2011) yaitu kegiatan pemasaran yang memicu konsumen untuk membicarakan, mempromosikan, merekomendasikan hingga menjual merek suatu produk kepada calon konsumen lainnya.

Word of mouth memiliki kekuatan besar yang berdampak pada perilaku pembelian konsumen. Rekomendasi dari teman yang sudah dipercaya, asosiasi, dan konsumen lain berpotensi untuk lebih dipercaya dibandingkan dari sumber komersil, seperti iklan dan salespeople. Sebagian besar, word of mouth terjadi secara alami, konsumen mulai dengan membicarakan sebuah merek yang mereka gunakan kepada orang lain. (Kotler \& Amstrong, 2012).

Berdasarkan teori mengenai word of mouth di atas, maka dapat disimpulkan bahwa word of mouth merupakan media promosi yang dilakukan dengan perantara orang untuk menyampaikan pesan mengenai suatu nilai produk/jasa yang telah digunakan kepada orang lain dan berdampak pada penilaian terhadap produk/jasa tersebut.

Dalam penelitian yang dilakukan Goyette, Ricard, Bergeron, dan Marticotte (2010) tentang skala pengukuran WOM, mereka mengusulkan beberapa indikator untuk mengukur WOM antara lain:

1. WOM intensity. Intensitas atau volume percakapan mengenai suatu produk yang terjadi dalam percakapan sehari-hari.

2. Positive valence WOM. Penilaian positif sebagai efek dari kepuasan yang didapatkan konsumen yang dituangkan dalam percakapan sehari-hari seperti pemberian rekomendasi atau ajakan untuk membeli suatu produk.

3. Negative valence WOM. Penyampaian hal-hal negatif kepada orang lain tentang suatu produk yang disebabkan oleh ketidakmampuan produk tersebut untuk memenuhi ekspektasi konsumen.

4. WOM Content. Isi percakapan atau konten pembahasan suatu produk seperti jenis, kualitas, harga, dan lain-lain.

\section{Motivasi Melakukan Word of Mouth}

Word of mouth yang dilakukan oleh konsumen merupakan salah satu hal yang harus diperhatikan oleh perusahaan karena sesuatu yang dibicarakan oleh konsumen mengenai suatu produk akan berimbas pada citra produk atau perusahaan tersebut, maka perusahaan harus dapat merangsang konsumen agar termotivasi untuk melakukan pembicaraan yang positif tentang produk atau perusahaan.

Konsumen yang termotivasi akan secara otomatis melakukan pembicaraan mengenai suatu produk. Octovate Consulting Group (Sriwedari, 2011) mengembangkan word of mouth dalam tiga tahapan, yaitu:

1. Talking. Tahap awal dimana pemilik merk harus dapat mengidentifikasi talkers yang tepat dan menyediakan topik yang menarik untuk dibicarakan.

2. Promoting. Tersedianya tools untuk talkers agar dapat dibagikan dan disebarkan kepada orang lain. 
3. Selling. Bagaimana agar bisa untuk mempengaruhi orang untuk "menjual" dan mempromosikan produk tersebut.

Perusahaan harus mampu mengubah persepsi bahwa Word Of Mouth hanyalah pembicaraan yang menarik saja, word of mouth bisa lebih dari itu. Disini suatu produk tidak sekedar dibicarakan dan dipromosikan, tetapi lebih dari itu, kegiatan word of mouth harus mampu mengubah perilaku konsumen, dari yang tidak membeli menjadi membeli dan dari yang berfikir skeptis menjadi tertarik untuk mencoba (Sumardy dkk, 2011).

\section{MenciptakanWord of Mouth}

Pemasar dapat melakukan berbagai cara untuk mendorong konsumen melakukan pembicaraan positif mengenai suatu produk. Menurut Sernovitz (2012) ada 4 hal yang dapat dilakukan agar orang lain membicarakan produk atau jasa dalam WOM Marketing, yaitu:

1. Be Interesting. Menciptakan suatu produk atau jasa yang menarik yang memiliki perbedaan, meskipun terkadang perusahaan menciptakan produk yang sejenis, mereka akan memiliki karakteristik tersendiri atau berbeda agar menarik untuk diperbincangkan. Perbedaan ini dapat dilihat dari berbagai hal seperti packaging, atau guarantee dalam produk atau tersebut.

2. Make it Easy. Memulai dengan pesan yang mudah diingat. Semua orang akan berbicara kepada teman mereka karena mereka memiliki topik percakapan sederhana yang menarik untuk dibagi.

3. Make People Happy. Membuat produk yang mengagumkan, menciptakan pelayanan yang prima, memperbaiki masalah yang terjadi, dan memastikan suatu pekerjaan yang dilakukan perusahaan dapat membuat konsumen membicarakan pro- duk kepada teman mereka. Word of mouth akan mudah terjadi apabila perusahaan dapat membuat konsumen merasa senang.

4. Earn Trust and Respect. Perusahaan harus mendapatkan kepercayaan dan rasa hormat dari pelanggan. Perusahaan harus selalu bersikap jujur, komitmen terhadap informasi yang diberikan, bersikap baik terhadap konsumen, memenuhi kebutuhan konsumen, dan membuat mereka bangga untuk membicarakan tentang produk atau jasa tersebut.

\section{Hubungan Word Of Mouth dengan Keputusan Pembelian}

Pembicaraan orang lain terhadap suatu produk menjadi bagian dari pertimbangan konsumen untuk memilihsuatu produk. Evaluasi alternatif dilakukan konsumen pada saat akan melakukan keputusan pembelian dengan word of mouth yang paling menarik. Konsumen cenderung lebih mempercayai penilaian dari orang lain dalam menilai sebuah produk dibandingkan iklan. Cerita dan pengalaman seseorang menggunakan sebuah produk terdengar lebih menarik yang bisa mempengaruhi pendengarnya untuk ikut mencoba produk tersebut.

Sumardy dkk. (2011) menyatakan tidak peduli perusahaan kecil atau besar, word of mouth communication tetap menjadi praktik pemasaran yang paling mendominasi keputusan pembelian konsumen terhadap produk apapun. Pernyataan tersebut senada dengan penelitian yang dilakukan Onbee Marketing Research bekerjasama dengan Majalah SWA (2009) membuktikan bahwa tingkat WOM Conversation (menceritakan kembali kepada orang lain) sebesar $85 \%$ dan menjadikan WOM sebagai sumber informasi untuk mengubah keputusannya sebesar $67 \%$. 


\section{KERANGKA KONSEPTUAL}

Berdasarkan landasan teori dan konsep yang dijabarkan di atas maka penelitian ini menganalisis pengaruh promosi melalui media sosial dan word of mouth terhadap keputusan pembelian. Varibel yang digunakan dalam penelitian ini adalah variabel independen yaitu promosi melalui media sosial $\left(\mathrm{X}_{1}\right)$ dan word of mouth $\left(\mathrm{X}_{2}\right)$ serta variabel dependen yaitu keputusan pembelian (Y). Penelitian ini digunakan untuk meneliti pengaruh masingmasing variabel independen terhadap variabel dependen dan pengaruh simultan dua variabel independen terhadap variabel dependen dengan kerangka konseptual sebagai berikut :

Gambar 6: Kerangka Konseptual

\section{Hipotesis}

Berdasarkan teori dan kerangka berpikir yang sudah diuraikan sebelumnya, maka dapat disusun beberapa hipotesis sebagai berikut:

H1 Promosi di media sosial berpengaruh terhadap keputusan pembelian di Bontacos.

$\mathrm{H} 2$ Word of mouth(WOM) berpengaruh terhadap keputusan pembelian di Bontacos.

H3 Promosi di media sosial dan word of mouth (WOM) secara simultan

\section{METODE PENELITIAN}

\section{Rancangan Penelitian}

Penelitian ini dilakukan untuk mengukur pengaruh antara variabel independen (promosi melalui media sosial dan word of mouth) terhadap variabel dependen (keputusan pembelian). Penelitian dilakukan dengan objek konsumen Bontacos dengan kisaran sampel yang digunakan adalah sebanyak 100 responden. Metode pengumpulan data adalah dengan penyebaran kuesioner. Skala pengukuran yang digunakan dalam penelitian ini adalah bipolar adjective. Data diolah dan diuji dengan beberapa teknik analisis data yang menggunakan software SPSS.

\section{Variabel Penelitian dan Defenisi Operasional}

Penelitian ini menggunakan tiga variabel yang terdiri dari dua variabel independen yaitu pro-mosi melalui media sosial (X1) dan word of mouth (X2) serta satu variabel dependen yaitu keputusan pembelian (Y). Definisi operasional dari ketiga variabel tersebut dapat dijabarkan sebagai berikut:

1. Promosi melalui media social. Promosi melalui media sosial yang dimaksud dalam penelitian ini mengacu pada pendapat Chris Heuer dalam Solis (2011) yaitu kegiatan promosi yang dilakukan Bontacos dengan menggunakan media sosial yang bertujuan untuk mempengaruhi keputusan pembelian konsumen dengan memberikan informasi-informasi kepada konsumen seputarkedai misalnya produk, harga, event, dan lain-lain, serta untuk berkomunikasi dan menjalin hubungan baik dengan pelanggan. Promosi melalui media sosial dapat diukur dengan indi-kator sebagai berikut: (a) context (b) communication (c) collaboration (d) connection.

2. Word of mouth. Word of mouth adalah proses komunikasi dari mulut ke mulut 
atau pertukaran informasi atau percakapan dua individu atau lebih. Hal tersebut mengacu pada penelitiaan yang dilakukan oleh Goyette, dkk (2010). Komunikasi tersebut berupa pembicaraan mengenai suatu produk, pemberian informasi dan rekomendasi dari sumber yang dipercaya oleh konsumen. Indikator untuk mengukur WOM yaitu: (a) WOM content (b) positive valence WOM (c) WOM intensity.

3. Keputusan Pembelian. Mengacu pada Kotler dan Amstrong (2011), yang dimaksud dengan keputusan pembelian adalah serangkaian proses yang dilakukan oleh konsumen untuk memutuskan pembelian suatu produk dari pengenalan kebutuhan hingga kegiatan pasca pembelian. Indikator untuk mengukur keputusan pembelian yaitu: (a) pengenalan kebutuhan (b) pencarian informasi (c) evaluasi alternatif (d) keputusan pembelian (e) perilaku pasca pembelian.

\section{Populasi dan Teknik Pengambilan Sampel Penelitian}

Populasi dari penelitian ini adalah konsumen kedai Bontacos yang jumlahnya tidak diketahui. Metode pengambilan sampel dengan menggunakan metode Non Probability Sampling dengan teknik Aksidental Sampling (Accidental Sampling).

\section{Skala Pengukuran}

Skala pengukuran yang digunakan dalam penelitian ini adalah bipolar adjective yang merupakan penyempurnaan dari semantic scale dengan harapan agar respon yang dihasilkan dapat merupakan intervally scaled data (Ferdinand, 2006). Skala yang digunakan pada rentang interval 1-10. Penggunaan skala 1-10 (skala genap) untuk menghindari jawaban responden yang cenderung memilih jawaban di tengah, sehingga akan menghasilkan respon yang mengumpul di tengah (grey area). Responden akan menilai pernyataanpernyataan dalam kuesioner dengan mengisi angka 1-10. Angka 1 berarti sangat tidak setuju hingga angka 10 berarti sangat setuju.

Dari hasil jawaban responden akan diinterpretasikan dengan angka indeks yang dikembangkan dengan rumus sebagai berikut :

Nilai indeks:

$$
\begin{aligned}
& ((\% F 1 \times 1)+(\% F 2 \times 2)+(\% F 3 \times 3)+(\% F 4 \times 4)+ \\
& (\% F 5 \times 5)+(\% F 6 \times 6)+(\% F 7 \times 7)+(\% F 8 \times 8)+ \\
& (\% F 9 \times 9)+(\% F 10 \times 10)) / 10
\end{aligned}
$$

Angka jawaban responden tidak berangkat dari angka 0 , tetapi mulai angka 1 hingga 10, maka angka indeks yang dihasilkan akan berangkat dari angka 10 hingga 100 dengan rentang sebesar 90, tanpa angka 0. Dengan menggunakan kriteria tiga kotak (Three-box Method), maka rentang sebesar 90 dibagi tiga akan menghasilkan rentang sebesar 30 yang akan digunakan sebagai dasar interpretasi nilai indeks, yaitu sebagai berikut (Ferdinand, 2006): a) $10,00-40=$ Rendah, b) $40,01-70=$ Sedang, c) 70,01-100 = Tinggi

\section{Analisis Regresi Berganda}

Persamaan regresi dalam penelitian ini digunakan sebagai penilaian seberapa besar pengaruh variabel independen yaitu promosi melalui media sosial $\left(\mathrm{X}_{1}\right)$ dan word of mouth $\left(\mathrm{X}_{2}\right)$, terhadap variabel dependen yaitu Keputusan Pembelian (Y).

\section{Uji Koefisien Determinasi $\left(\mathbf{R}^{2}\right)$}

Pengaruh tinggi rendahnya koefisien determinasi tersebut digunakan pedoman yang dikemukakan oleh Guilford yang dikutip oleh Supranto (2001) adalah sebagai berikut : 
Tabel 1:

Pedoman Interpretasi Koefisien Determinasi

\begin{tabular}{|l|l|}
\hline \multicolumn{1}{|c|}{ Pernyataan } & \multicolumn{1}{c|}{ Keterangan } \\
\hline$>4 \%$ & Pengaruh Rendah Sekali \\
\hline $5 \%-16 \%$ & Pengaruh Rendah Tapi Pasti \\
\hline $17 \%-49 \%$ & Pengaruh Cukup Berarti \\
\hline $50 \%-81 \%$ & Pengaruh Tinggi atau Kuat \\
\hline$>80 \%$ & Pangaruh Tinggi Sekali \\
\hline
\end{tabular}

Sumber : Supranto (2001)

\section{HASIL PENELITIAN DAN PEMBAHASAN}

\section{Karakteristik Responden}

Berdasarkan hasil penyebaran kuesioner kepada 100 orang responden diketahui bahwa sebagian besar responden dalam penelitian ini adalah berjenis kelamin perempuan yaitu sebanyak 77 orang atau sebesar $77 \%$, dan responden berjenis kelamin laki-laki sebanyak 23 orang atau sebesar 23\%. Hasil tersebut diinterpretasikan bahwa para konsumen perempuan lebih sering berkumpul dengan teman sesama perempuan untuk mencoba berkunjung ke tempat-tempat yang baru dan unik seperti kedai Bontacos. Keputusan pembelian maha-siswi juga dinilai lebih mudah terpengaruh oleh teman di lingkungan sekitarnya atau informasi di media sosial, sehingga akan menjadikan kesamaan dalam memilih suatu produk yang akan di konsumsi.

Sedangkan berdasarkan rentang usia responden diketahui bahwa sebagian besar responden dalam penelitian ini adalah responden yang berusia antara 19-22 tahun yaitu sebesar $45 \%$ atau sebanyak 45 orang, responden yang berusia antara 23-26 tahun sebesar $29 \%$ atau sebanyak 29 orang, responden yang berusia 15-18 tahun sebesar 16\% atau sebanyak 16 orang, dan responden yang berusia di atas 26 tahun sebesar $10 \%$ atau sebanyak
10 orang. Dari hasil perhitungan tersebut dapat diinterpretasikan bahwa responden yang berusia 19-22 tahun lebih sering menghabiskan waktu untuk bersosialisasi dengan teman atau kerabat dengan memilih tempat yang cocok dengan gaya hidup masa kini.

Sedangkan gambaran responden berdasar jenis pekerjaan menunjukkan bahwa sebagian besar responden dalam penelitian ini adalah mahasiswa dan pelajar dengan prosentase sebesar $49 \%$, kemudian karyawan swasta sebesar 36\%, PNS (Pegawai Negeri Sipil) sebesar $9 \%$, dan wirausaha sebesar $6 \%$. Dari gambar di atas dapat diinterpretasikan, meskipun prosentase konsumen dari kalangan mahasiswa dan pelajar sangat tinggi, namun secara umum konsumen Bontacos sebagian besar berasal dari kalangan pekerja, baik karyawan swasta, PNS, ataupun wirausaha.

\section{Model Analisis Regresi}

Untuk mengetahui pengaruh promosi melalui media sosial terhadap keputusan pembelian digunakan analisa Model Analysis Regression berganda dengan program SPSS sebagai berikut :

Tabel 2:

Koefisiensi Model Analysis Regression

\begin{tabular}{|c|c|c|c|c|c|c|}
\hline \multicolumn{7}{|c|}{ Coefficients $^{\mathrm{a}}$} \\
\hline \multirow{2}{*}{\multicolumn{2}{|c|}{ Model }} & \multicolumn{2}{|c|}{$\begin{array}{l}\text { Unstandardized } \\
\text { Coefficients }\end{array}$} & \multirow[t]{2}{*}{$\begin{array}{l}\text { Standardized } \\
\text { Coefficients }\end{array}$} & \multirow[t]{2}{*}{$T$} & \multirow[t]{2}{*}{ Sig. } \\
\hline & & Std. Error & Beta & & & \\
\hline \multirow[t]{3}{*}{1} & (Constant) & 39,999 & 6,200 & & 6,451 &, 000 \\
\hline & Media Sosial & 324 & 086 & 358 & 3,781 & ,000 \\
\hline & WOM & 301 & 108 & 263 & 2,781 & ,007 \\
\hline
\end{tabular}

Sumber : Hasil perhitungan SPSS 20

Dari tabel tersebut maka dapat dituliskan bahwa persamaan regresi berganda untuk modal yang peneliti gunakan adalah sebagai berikut : 


$$
\begin{aligned}
& Y=a+b X_{1}+b X_{2}+e \\
& Y=39,999+0,324 X_{1}+0,301 X_{2}+e
\end{aligned}
$$

Dari hasil perhitungan tersebut dapat ditarik kesimpulan bahwa jika terjadi peningkatan kinerja promosi melalui media sosial, dan juga penerapan strategi untuk merangsang penyebaran WOM yang lebih luas, maka keputusan pembelian konsumen akan meningkat.

\section{Uji t}

Uji $\mathrm{t}$ digunakan untuk mengetahui pengaruh dari masing-masing variabel independen terhadap variabel dependen. Berikut adalah hasil output program SPSS untuk uji t:

\begin{tabular}{|c|c|c|c|c|c|c|}
\hline \multicolumn{7}{|c|}{ Coefficients $^{\mathrm{a}}$} \\
\hline \multirow{2}{*}{\multicolumn{2}{|c|}{ Model }} & \multicolumn{2}{|c|}{$\begin{array}{l}\text { Unstandardized } \\
\text { Coefficients }\end{array}$} & \multirow[t]{2}{*}{$\begin{array}{l}\text { Standardized } \\
\text { Coefficients }\end{array}$} & \multirow[t]{2}{*}{$\bar{T}$} & \multirow[t]{2}{*}{ Sig. } \\
\hline & & $\begin{array}{l}\text { Std. } \\
\text { Error }\end{array}$ & Beta & & & \\
\hline \multirow[t]{3}{*}{1} & (Constant) & 39,999 & 6,200 & & 6,451 & ,000 \\
\hline & Media Sosial & ,324 & 086 & ,358 & 3,781 & ,000 \\
\hline & WOM & ,301 & , 108 & ,263 & 2,781 & 007 \\
\hline
\end{tabular}

Tabel 3: Hasil uji t

Sumber : Hasil perhitungan SPSS 20

Hasil perhitungan uji t pada tabel di atas dapat dijelaskan sebagai berikut :

1. Promosi Melalui Media Sosial $\left(\mathrm{X}_{1}\right)$. Hasil perhitungan uji regresi untuk variabel promosi melalui media sosial diperoleh nilai signifikansi sebesar 0,000. Karena nilai tersebut lebih kecil dari 0,05 (0,000 $<0,05)$ maka hipotesis pertama ( $\mathrm{H} 1)$ yang menyatakan "Terdapat pengaruh promosi melalui media sosial terhadap keputusan pembelian di Bontacos.” Diterima.

2. Word Of Mouth (X2). Hasil perhitungan uji regresi untuk variabel word of mouth diperoleh nilai signifikansi sebesar 0,007. Karena nilai tersebut lebih kecil dari 0,05 $(0,007<0,05)$ maka hipotesis kedua $(\mathrm{H} 2)$ yang menyatakan "Terdapat pengaruh word of mouth terhadap keputusan pembelian di Bontacos." Diterima.

\section{Uji F}

Uji $F$ digunakan untuk mengetahui pengaruh secara bersama-sama atau simultan semua variabel independen terhadap variabel dependen. Berikut adalah hasil output program SPSS untuk uji F :

\section{Tabel 4: Hasil uji F}

\begin{tabular}{|l|l|r|r|r|r|r|}
\hline \multicolumn{7}{|l|}{ ANOVA $^{\text {a }}$} \\
\hline \multicolumn{2}{|l|}{ Model } & $\begin{array}{c}\text { Sum of } \\
\text { Squares }\end{array}$ & df & $\begin{array}{c}\text { Mean } \\
\text { Square }\end{array}$ & F & Sig. \\
\hline \multirow{2}{*}{1} & Regression & 873,398 & 2 & 436,699 & 18,398 &, $000^{b}$ \\
\cline { 2 - 8 } & Residual & 2302,392 & 97 & 23,736 & & \\
\cline { 2 - 7 } & Total & 3175,790 & 99 & & & \\
\hline \multicolumn{7}{|l|}{ a. Dependent Variable: Keputusan Pembelian } \\
\hline \multicolumn{6}{|l|}{ b. Predictors: (Constant), WOM, Media Sosial } \\
\hline
\end{tabular}

Sumber : Hasil perhitungan SPSS 20

Hasil perhitungan uji $\mathrm{F}$ pada Tabel di atas menunjukkan nilai signifikansi sebesar 0,000 . Karena nilai tersebut lebih kecil dari $0,05(0,000<0,05)$ maka hipotesis kedua (H3) yang menyatakan "Terdapat pengaruh promosi melalui media sosial dan word of mouth secara simultan terhadap keputusan pembelian di Bontacos" Diterima.

\section{Uji Koefisien Determinasi $\left(\mathbf{R}^{2}\right)$}

Koefisien determinasi $\left(\mathrm{R}^{2}\right)$ dimaksudkan untuk mengetahui tingkat ketepatan paling baik dalam analisa regresi dimana hal yang ditunjukan oleh besarnya koefisien determinasi $\left(\mathrm{R}^{2}\right)$ antara 0 (nol) dan I (satu). Apabila koefisien determinasi semakin mendekati satu, maka dapat dikatakan bahwa variabel independen semakin berpengaruh 
terhadap variabel dependen.

Tabel 5: Hasil uji $\boldsymbol{R}^{2}$

\begin{tabular}{|l|r|r|r|r|}
\hline \multicolumn{5}{|c|}{ Model Summary } \\
\hline Model & $R$ & $R$ Square & $\begin{array}{c}\text { Adjusted R } \\
\text { Square }\end{array}$ & $\begin{array}{c}\text { Std. Error of the } \\
\text { Estimate }\end{array}$ \\
\hline 1 &, $524^{\mathrm{a}}$ &, 275 &, 260 & 4,872 \\
\hline \multicolumn{7}{|c|}{ a. Predictors: (Constant), WOM, Media Sosial } \\
\hline
\end{tabular}

Sumber: Hasil perhitungan SPSS 20

Berdasarkan pada Tabel di atas hasil perhitungan diperoleh nilai $\mathrm{R}$ Square sebesar 0,275 . Hal ini berarti bahwa promosi melalui media sosial dan word of mouth berperan cukup baik dalam mempengaruhi konsumen untuk menentukan keputusan pembelian di Bontacos yaitu sebesar $27,5 \%$, sedangkan sisanya sebesar $72,5 \%$ dijelaskan oleh variabel lain yang tidak terdapat dalam model penelitian ini seperti harga, lokasi, fasilitas dan lain-lain.

\section{Pengaruh Promosi Melalui Media Sosial Terhadap Keputusan Pembelian}

Hasil penelitian menunjukkan bahwa promosimelaluimediasosialberpengaruhpositif dan signifikan terhadap keputusan pembelian di Bontacos. Tjiptono (2008) menyatakan bahwa promosi merupakan salah satu faktor penentu keberhasilan suatu program pemasaran. Dalam hal ini Bontacos menggunakan media sosial sebagai media promosi karena dirasa sangat efektif dan efisien, serta peningkatan jumlah pengguna media sosial terus meningkat setiap tahun membuat informasi yang dibagikan di media sosial dapat terus menyebar lebih luas. Bontacos juga dapat menjalin hubungan baik dengan konsumen melalui media sosial. Kotler \& Amstrong (2012) Jaringan sosial media ini merupakan bentuk baru dari dialog antara "consumer-to-consumer" dan "business-toconsumer" yang memiliki implikasi besar terhadap pemasar.

Hasil penelitian ini juga didukung oleh penelitian sebelumnya yang dilakukan oleh Singgih Nurgiyantoro tahun 2014, yang menyebutkan bahwa promosi melalui media sosial berpengaruh positif dan signifikan terhadap keputusan pembelian konsumen.

\section{Pengaruh Word Of Mouth Terhadap Keputusan Pembelian}

Hasil penelitian menunjukkan bahwa word of mouth berpengaruh positif dan signifikan terhadap keputusan pembelian di Bontacos. Hal tersebut senada dengan pernyataan Sumardy dkk. (2011) yang menyatakan bahwa "tidak peduli perusahaan kecil atau besar, word of mouth communication tetap menjadi praktik pemasaran yang paling mendominasi keputusan pembelian konsumen terhadap produk apapun."

Pembicaraan orang lain terhadap suatu produk menjadi bagian dari pertimbangan konsumen untuk memilih suatu produk. Evaluasi alternatif dilakukan konsumen pada saat akan melakukan keputusan pembelian dengan word of mouth yang paling menarik. Konsumen cenderung lebih mempercayai word of mouth communication dalam menilai sebuah produk dibandingkan iklan. Cerita dan pengalaman seseorang menggunakan sebuah produk terdengar lebih menarik yang bisa mempengaruhi pendengarnya untuk ikut mencoba produk tersebut. Fenomena word of mouth communication diyakini bisa mendorong pembelian oleh konsumen, bisa mempengaruhi komunitas, efisien karena tidak memerlukan budget yang besar (low cost), bisa mencipatakan image positif bagi produk, dan bisamenyentuh emosi konsumen. (Sumardy dkk., 2011).

Hasil penelitian ini juga didukung oleh penelitian sebelumnya yang dilakukan oleh Yuda Oktavianto tahun 2014, yang menyebutkan bahwa word of mouth berpengaruh 
positif dan signifikan terhadap keputusan pembelian konsumen.

\section{Pengaruh Promosi Melalui Media Sosial dan Word Of Mouth Secara Simultan Terhadap Keputusan Pembelian}

Hasil pengujian hipotesis dalam penelitian ini menunjukkan bahwa promosi melalui media sosial dan word of mouth Secara Simultan Terhadap Keputusan Pembelian di Bontacos. bagi Bontacos yang merupakan kedai yang tergolong baru di Jombang, promosi melalui media sosial dan WOM merupakan cara yang sangat efektif dan efisien dalam hal penyebaran informasi. Konsumen akan mengumpulkan berbagai informasi sebelum memutuskan membeli atau mengkonsumsi suatu produk.

Konsumen juga akan membandingkan sebagian atau seluruh informasi yang mereka terima. Hal tersebut senada dengan pernyataan Philip Kotler (1998), “konsumen mempelajari merek-merek yang tersedia dari ciri-cirinya. Informasi ini digunakan untuk mengevaluasi semua alternatif yang ada dalam menentukan keputusan pembeliannya. Konsumen mendapatkan informasi mengenai Bontacos melalui media sosial, selanjutnya konsumen juga cenderung akan mencari dan membandingkan informasi tersebut dengan testimoni dari konsumen lain. Maka perlu strategi yang baik dalam menggabungkan kedua faktor tersebut agar dapat meningkatkan keputusan pembelian konsumen.

Strategi yang berkaitan dengan promosi melalui media sosial dan WOM yang baik akan dapat memberikan pengaruh yang cukup signifikan terhadap keputusan pembelian konsumen dalam memilih suatu produk yang akan dibeli. Karena tidak dapat di pungkiri juga mempertimbangkan kedua faktor tersebut dalam pemilihan produk. Informasi yang jelas dan menarik di media sosial, dan juga diikuti dengan terjadinya WOM positif akan sangat mudah mempe-ngaruhi keputusan pembelian konsumen.

\section{PENUTUP}

\section{Simpulan}

Berdasarkan pembahasan di atas disimpulkan bahwa Promosi melalui media sosial menjadi strategi pemasaran yang cukup efektif, serta didukung dengan word of mouth yang positif akan mampu menarik konsumen untuk melakukan pembelian di kedai Bontacos.

\section{Saran}

Berdasarkan hasil temuan disarankan: (1) agar kegiatan promosi melalui media sosial,Bontacos harus lebih aktif, mampu memberikan inovasi-inovasi dan penyajian pesan yang lebih unik dan menarik agar konsumen dapat lebih memahami dan tertarik dengan informasi yang diposting di media sosial, sehingga dapat lebih memberikan pengaruh dalam pengambilan keputusan pembelian. (2). Bontacosdiharapkan dapat menerapkan strategi khusus untuk merangsang konsumen agar memberikan testimoni atau melakukan pembicaraan yang positif dengan oranglain, misalnya dengan meningkatkan nilai produk beserta atributnya untuk menambah kepuasan konsumen. (3). Bontacos juga harus memiliki strategi untuk memantau percakapan yang terjadi di kalangan konsumen agar dapat mengetahui posisi Bontacos dalam benak konsumen, kemudian Bontacos dapat mengklarifikasi testimoni negatif serta mempertahankan dan meningkatkan value Bontacos yang mendapat testimoni positif. 


\section{DAFTAR PUSTAKA}

Devito, Joseph. 2011. Komunikasi Antar Manusia. Tanggerang Selatan. Karisma Publishing Group.

Belch, George E., Belch, Michael A. 2009. Advertising and Promotion : An Integrated Marketing Communication Perpective, 8th Edition. New York. McGraw-Hill Companies.

Fandy, Tjiptono. 2008. Strategi Bisnis Pemasaran. Yogyakarta. Andi.

Ferdinand, Augusty. 2006. Metode Penelitian Manajemen: Pedoman Penelitian untuk skripsi, Tesis dan Disertai Ilmu Manajemen. Semarang. Universitas Diponegoro.

Ghozali, Imam. 2006. Aplikasi Analisis Multivarite dengan SPSS, Cetakan Keempat. Semarang. Universitas Diponegoro.

Goyette, Isabelle. 2012. "Word-of-Mouth Measurement Scale for e-Services Context”. Jurnal Word of Mouth. Dalam Dimensi Word of Mouth.

Goyette, I., Ricard, L., Bergeron, J., and François Marticotte. 2010. e-WOM Scale: Word-of-Mouth Measurement Scale for e-Services Context. Canadian Journal of Administrative Sciences

Gurnelius, Susan. 2011. 30-minute Sosial Media Marketing. United States. McGraw-Hill Companies.

Hermawan, Agus. 2012. Komunikasi Pemasaran. Jakarta. Erlangga

Ibnu, Widiyanto, 2008. Pointers : Metodologi Penelitian. Semarang. BP Undip

Kotler dan Keller. 2007. Manajemen Pemasaran, Jilid 1, Edisi 12. Jakarta. Indeks.

Kotler dan Keller. 2009. Manajemen Pemasaran, Jilid I, Edisi 13. Jakarta. Erlangga

Kotler, Philip dan Amstrong, Gary. 2001. Prinsip-prinsip Pemasaran, Jilid 1 dan 2, Edisi 8. Jakarta. Erlangga.

Kotler, Philip dan Amstrong, Gary. 2012. Prinsip-Prinsip Pemasaran, Edisi 13, Jilid 2. Jakarta. Erlangga.

Kotler, Philip. 1998. Manajemen Pemasaran : Analisis, Perencanaan, Implementasi dan Pengendalian, (alih bahasa : Hendro Teguh, dan Ronny A. Rusli) Jilid 2, Jakarta. Prenhalindo.

Kotler, Philip. 2004. Manajemen Pemasaran : Analisis, Perencanaan, implementasi dan Kontrol, Edisi Sebelas, (alih Bahasa, Hendra Teguh). Jakarta. Prenhalindo.

Nurgiyantoro, Singgih. 2014. Pengaruh Strategi Promosi Melalui Social Media Terhadap Keputusan Pembelian Garskin Yang Dimediasi Word Of Mouth 
Marketing (Studi Pada Konsumen Produk Garskin Merek Sayhello Di Kota Yogyakarta). Yogyakarta. Universitas Negeri Yogyakarta

Peter, P, J, \& Olson, Jerry, C. 2009. Costumer Behavior, Jilid 2, Edisi Kelima (alih bahasa Damos Sihombing). Jakarta. Erlangga.

Sernovitz, Andy. 2012. Word of Mouth Marketing. Amerika. Greenleaf Book Group Press.

Solis, Brian. 2010. Engage: The Complete Guide for Brands and Business to Build, Cultivate, and Measure Success in the New Web. New Jersey. John Wiley \& Sons Inc.

Sriwedari, Enggal. 2011. Word Of Mouth Sebagai Efek Respon Positif Dari Kepuasan Konsumen Dan Dampaknya Pada Pembelian Kembali: Studi Kasus Mahasiswa Sebagai Konsumen Yoghurt Activia. Jakarta. 2011

Sugiyono. 2008. Metode Penelitian Kuantitatif Kualitatif dan R\&D. Bandung Alfabeta.

Sugiyono. 2004. Statistika untuk Penelitian, Cetakan Keenam. Bandung. Alfabeta.

Sumardy, dkk., 2011. The Power of Word of Mouth Marketing. Jakarta. Gramedia Pustaka Utama.

Supranto, dan Limakrisna, Nandan. 2011. Perilaku Konsumen dan Strategi Pemasaran, Edisi Kedua. Jakarta. Mitra Wacana Media.

Sutisna. 2001. Perilaku Konsumen dan Komunikasi Pemasaran. Bandung. PT. Remaja Rosdakarya.

Taprial, Varinder \& Kanwar, Priya. 2012. Understanding Social Media. London. Ventus Publishing ApS.

Wenats, AG Eka dkk. 2012. Integrated Marketing Communications : Komunikasi Pemasaran di Indonesia. Jakarta. Gramedia Pustaka Utama.

http://www.wikipedia.com

http://www.wearesocial.com

Majalah SWA (SWA08/XXV/16-29 April 2009) 